\title{
Student Wellbeing Through Teacher Wellbeing: A Study with Law Teachers in the UK and Australia
}

\author{
Colin James \\ Australian National University, Canberra, Australia \\ Caroline Strevens \\ University of Portsmouth, Portsmouth, United Kingdom \\ Rachael Field \\ Bond University, Gold Coast, Australia \\ Clare Wilson \\ University of Portsmouth, Portsmouth, United Kingdom
}

\begin{abstract}
Research confirms law students and lawyers in the US, Australia and more recently in the UK are prone to symptoms related to stress and anxiety disproportionately to other professions. In response, the legal profession and legal academy in Australia and the UK have created Wellness Networks to encourage and facilitate research and disseminate ideas and strategies that might help law students and lawyers to thrive. This project builds on that research through a series of surveys of law teachers in the UK and Australia on the presumption that law teachers are in a strong position to influence their students not only about legal matters, but on developing attitudes and practices that will help them to survive and thrive as lawyers. The comparative analysis reveals several differences, but also many similarities with law teachers in both countries reporting negative effects from neoliberal pressures on legal education programs that impact their wellbeing, performance as teachers and ability to adequately respond to student concerns.
\end{abstract}

Keywords: Wellbeing; law teacher; student wellbeing; legal education; psychological distress

\section{Introduction}

Student wellbeing in legal education has been a growing concern internationally for some decades. Beginning in the United States and now including networks of researchers in Australia and the UK, studies confirm high rates of psychological distress among law students which sometimes continues beyond graduation, impacting on members of the legal profession (Bergin \& Pakenham, 2014; Foley et al., 2016; Krieger, 1998, Krieger \& Sheldon, 2015).The latest development in this research has extended the focus to include the wellbeing of law teachers, on the assumption that some and possibly many law students model attitudes, beliefs and practices they perceive in their professional educators. If law student wellbeing needs to improve then it is reasonable to hope and expect law teachers' wellbeing to be sound. Teachers are in the best position to encourage, motivate and respond to students' concerns about surviving the stress of law school as well as entering a stressful profession, and to support their capacity to flourish.

This work is licensed under a Creative Commons Attribution 4.0 International Licence. As an open access journal, articles are free to use with proper attribution. ISSN: 2205-0795 
Among recent publications related to academic wellbeing is the report by the UK's Higher Education Policy Institute (Morrish, 2019) which found escalating rates of poor mental health in staff at 59 universities. There were significant increases in several indicators including referrals for occupational health, excessive workloads often dominated by 'audit and metrics' rather than teaching and student support, reduced employment security and heightened 'performance management' linked to short-term outcomes that many teachers found unattainable. Another UK project involved a study led by Dr Clare Wilson and Caroline Strevens at the University of Portsmouth (Wilson \& Strevens, 2018) which analysed responses by 185 law academics to questions related to their psychological wellbeing using Carol Ryff's (1989) model. Ryff's model has six factors and six subscales that have been widely used and validated to measure psychological wellbeing, namely: autonomy, environmental mastery, personal growth, positive relations with others, purpose in life and self-acceptance. That project found that "law teachers who reported higher levels of depression, anxiety and stress also experienced an inability to live according to their values, little ability to control their environment around them and they tended to blame themselves" (Wilson \& Strevens, 2018, p. 344). The law teachers reporting high stress also had low scores on 'hope', high obstruction of values and significantly less environmental mastery, highlighting the importance of autonomy for law teachers. The study indicated that not all stress was negative, "however, where it relates to obstruction of one's values, and lack of control over one's life, then stress erodes wellbeing" (Wilson \& Strevens, 2018, p. 345). These findings highlight the importance of being able to fulfill one's personal values and having some degree of autonomy at work. This quantitative data is supported by the qualitative analysis which is a focus of the discussion in this article. Our analysis of the qualitative data also found a significant cause of law teacher stress was a shortage of resources to assist students in difficulty, and that overall law teachers tended to associate stress with work, and wellbeing with homelife and friends. Two additional papers have reported on this research in Australia and the UK (James, Strevens, Field \& Wilson, 2020; James, Strevens, Field \& Wilson, 2019). This article provides further qualitative analysis of that research data, probing deeper into the experience and suggestions of law teachers in both countries.

\section{A Background of Neoliberalism}

In order to understand the findings and insights from our research, including the context of the lived experience of law teachers, it helps to interrogate the impact of recent changes in tertiary education systems in contemporary, developed nations which are consistent with broader cultural and political changes described as neoliberalism (Davies, 2016; Saunders, 2007). Specifically, in the UK and Australia, universities have been subjected to reduced government support, requiring them to seek increased funding from private sources including sponsorships and direct student fees. The effects of this seemingly simple change have been deep and broad, including increased austerity on university programs and staff, focusing on efficiencies intended to improve productivity by cutting costs and increasing measurable outputs. Part of the neoliberal strategy includes shifts in language so that students are now customers, consistent with the shift towards a market model of selling education as the university's product.

Critical responses to this 'corporatisation of universities' and the 'commodification of knowledge' has been strong and ongoing, but so far ineffective (Sims, 2019; Thornton, 2014a). Increasing demand for student places has enabled universities to ignore criticism of treating students as mere consumers of product (Hil, 2015). Similarly, increasing competition has led universities to rely on metrics and 'league tables' of questionable validity and limited relevance to the quality of education, as they try to prove their 'excellence' across other measures (Mok \& Neubauer, 2016). The effects on academics have been negative and material, often teaching increased class sizes with reduced resources including fewer administrative support staff and related increases in administrative responsibilities (Deem, 1998; Thornton, 2014b). Many academics are struggling, particularly in the UK, where some have an additional role as personal tutors providing pastoral care for students (Student Minds, 2014).

A central aim of our research project, in the light of these additional systemic pressures on teaching staff, is to conduct a longitudinal investigation of legal academics' perception of their own wellbeing as one indicator of their actual levels of coping or thriving. Another aim is to give a voice to law teachers who might have good ideas for positive systemic changes likely to improve their wellbeing. Surveying teachers in two countries enables a comparative analysis that could reveal jurisdictional or cultural differences in influencing wellbeing that might otherwise remain hidden. One hypothesis for the study is that if the wellbeing of teachers could be improved, even within the neoliberal management agenda, it might have flow-on beneficial effects for the wellbeing of their students, or at least provide insights into other changes that might benefit law students. 


\section{Method}

The current project involved two follow-up studies in the UK and Australia in 2017, in which university law teachers were invited to complete a survey that included well-validated instruments such as the Quality of Working Life (QoWL), Stress Mindset, and the Work Engagement Scale (WEL). The UK survey attracted 132 participants and the Australian survey, based on a slightly modified instrument to suit the different jurisdiction, had 161 participants.

The surveys included open and closed questions to enable mixed-method analysis including thematic, phenomenographical analysis which explores the different ways people understand the same concept or phenomenon (Akerlind, 2005). The researchers also applied the principles in Self-Determination Theory (SDT), including the focus on intrinsic motivation over extrinsic, and the positive psychology triad consisting of autonomy, competence and relatedness (Ryan \& Deci, 2000). In analysing the qualitative data we found the most informative responses came from participant responses to the question: Please explain what you think your university could do to improve staff quality of working life.

\section{Results}

In both countries the results confirmed a main finding in the original UK study, that law teachers were more focused on their students' wellbeing than their own. A majority reported being satisfied in their role at work, based on having a clear set of goals to help them do their job (72\% in Australia and 60\% in the UK), being satisfied with working hours (66\% in Australia and 63\% in the UK), and satisfied with life in general (66\% in Australia and 59\% in the UK). However, significant minorities showed symptoms and signs of being at risk of mental illness. While no participants in either country scored at extreme severity on any of the scales, of the combined group 32\% showed major signs of depression, $30 \%$ major signs of anxiety and $42 \%$ major signs of stress. One note of difference between the cohorts was the response to the neoliberal initiative of having to treat students as consumers as opposed to learners, which $78 \%$ of Australian law teachers found stressful compared with $50 \%$ in the UK.

The qualitative data provided rich information to help understand some of the causes of law teacher stress. In particular, the SDT analysis produced two main themes. First, poor management styles, related to structural changes, are causing confusion about strategic reputation and priorities for research and teaching. Second, the changes reflect a lack of transparency and a lack of respect, leading to reduced autonomy, increased workload and administrative burdens.

\section{Management Styles}

Participating law teachers in both countries were generally critical of university management and systems, reflecting on what they saw as neoliberal changes such as the 'obsession' with rankings and metrics, and top-down and micro-management styles. In response to the qualitative question about how the university systems could change to improve teachers' quality of working life, many comments from both cohorts sought changes in management designed to improve the quality of teaching and the student experience, consistent with the apparently self-less and professional attitude of many respondents.

Several referred to a 'gulf' between what universities offered students in relation to the quality of the learning experience, and the reality of spending significant resources on symbolic images 'such as the size of the atrium' in order to establish a worldclass reputation. Some respondents believed that universities are caught up in an international market and have no choice but to compete on the same rules.

The university is responding to global neoliberal competitiveness narratives in the same way as many other universities: students as consumers, decreasing public funding. (UK)

... stop patronising people with ridiculous cultural change workshops; stop using neoliberal language. (Aust)

Others felt the imposed marketizing process compromises the academic profession, so they are merely selling a product consistent with a student-as-customer or consumer perspective. However, many teachers remained strongly focused on student learning, development and wellbeing.

My colleagues and I will happily spare an hour of our time to talk to a student one-to-one about what they want from law, and from life, about a moot, about a forthcoming interview. This can't be timetabled, and it can't be audited. It receives no institutional recognition; we do it, knowing that, because we remain professionals. (UK) 
Universities should not be (operating) as marketing devices for some product. (Aust)

Several participants reported their university management was willing to rely on student evaluations of teaching, an increasingly discredited practice, instead of valid measures of student learning and development (Lawrence, 2018). Consequently, many teachers felt, as one respondent put it, assessed "based on metrics that (are) ... not clearly linked to student learning". The anonymous nature of student feedback on teaching enables mischievous and untrue criticisms that damage the morale of teachers and undermine their autonomy further as management appears to take the process seriously in order to "keep the customers happy" (Bunge, 2018).

\begin{abstract}
(Universities should) ... stop acting as though they believe that students know better than lecturers about how and what they should be taught. Stop relying on student feedback to determine how a lecturer is performing in their role and stop manipulating that feedback by organising it to happen at the same time as feedback on written work is being delivered to students. (UK)
\end{abstract}

(Universities should) ... de-emphasise raw student evaluation scores, especially when response rates are low and confidence intervals are large. (Aust)

One comment was insightful in identifying a 'gulf' between the apparent self-interest of management and the professionalism of teachers, reflecting the views of many others who provided examples from their experience.

A gulf has developed between the values of senior management and those of teachers. The former are obsessed with finance and appearances. The latter are committed to doing what will provide the best experience for their students. The feeling has become one of mutual incomprehension. In so far as senior management actually realises the lengths we will go to for our students, they deprecate it as an improper use of resources. This stand-off creates very considerable stress. To add insult to injury, their pay rises, while ours is stationary or worse. (UK)

The increased administrative burden combined with the lack of transparency or consultation with law teachers led some respondents to feel unsupported in an increasingly alienating system. Suggestions for improvement included smaller classes, employing more teachers, reducing workloads to enable teaching preparation and feedback to students on assessments, improved consultation on decisions affecting students, and valuing teaching as much as research.

Cut down needless bureaucracy, better admin support, less performance management,

clearer and more realistic expectations. (UK)

The SINGLE change that needs to happen ... that would change every academic's life for the better would be to locate administrative staff back into the schools! (Aust)

\title{
Autonomy
}

A recent meta-analysis has confirmed the importance of autonomy for individual wellbeing, concluding that enhanced autonomy is likely to be more beneficial and have broader effects than increased wealth (Fischer \& Boer, 2011). A smaller study on the effect of academic support programs on law students found simply enhancing the perception of autonomy was sufficient to improve individual wellbeing (Schulze \& Ding, 2012). In the current study, law teachers in both countries reported experiencing reduced autonomy following imposed increases in workload and administrative tasks, which helps explain some of the findings relating to stress and anxiety. In making the changes, responses indicated that university management often fails to consult teachers who typically have the relevant experience and practical knowledge in terms of how the changes will affect students and their learning experience.

There is NO capacity (by law teachers) to actually make any meaningful contribution to decisions, as micromanagers (likely with contractual bonuses attached to KPIs) continuously erode academic autonomy. (Aust)

Workload increases further undermine autonomy because the steadily increasing administrative burdens, called by one respondent the 'admin drift', and accretive cost-cutting strategies leave less time and resources for teaching preparation and engaging with students that teachers believe is central to their role. 
Academics are increasingly performing large administrative tasks whilst simultaneously being required to deliver increasingly higher research and teaching outputs. (Aust)

Some referred to the lack of planning and failures to leverage organisational strengths to improve quality of performance and outcomes.

(there should be ...) more consultation about change and planning. (Aust)

I spend a lot of my time in numerous mundane administrative tasks which are not cost effective given my salary grade. This does not make commercial sense. (UK)

There is too much autonomy in matters where support would assist and little or no autonomy in important pedagogical matters like the timing and nature of assessment. (Aust)

Academic research has acquired renewed status within university management because of the potential for sponsorship and external funding grants, however while law teachers are encouraged to do more research at prestigious levels they are also expected to maintain and sometimes increase their teaching outputs with larger classes.

... my research days are regularly infringed, there is no robust defence of research time. (UK)

My colleagues and I are exhausted. I cannot continue to perform or live this way and am actively looking to leave. (UK)

Reduced autonomy is reflected in comments by several participants describing impacts on workload due to "repeated restructures". These changes may involve new goals and activities driven by top-down priorities often formed without consulting teaching staff or without any apparent awareness of the impact on teaching loads, law school programs or students.

I find change fatigue one of the most challenging aspects of my working life. (UK)

Stop changing the 'goal posts'. First, we were required to focus on the quantity of our publications, then quality, then quantity, and now impact. Nothing is 'good enough'. (Aust)

The risk of burnout is extreme ... (UK)

In both countries law teachers seemed acutely aware of the neoliberal background to many of the changes imposed on them and the law school by the university. Consistent with the HEPI study in the UK (Morrish, 2019) law teachers critiqued 'performance management' based on short-term metrics rather than student learning and development. However, the feeling they expressed was frustration at being at the 'end of the line' together with students for whom they feel responsible. The responses showed that many law teachers are aware of the contradiction, given the importance of providing autonomy support for their students, while losing their own autonomy which in turn impacts their ability to meet the students' needs.

Changes to systems etc are increasingly made without any reference to those of us at the coal-face who actually do the work, and support is increasingly centralised and inaccessible to those of us who need it. (Aust)

While many Australian law teachers felt providing one-to-one student support and interaction was an important part of their job, they felt it was unsupported and not valued by management. However, in the UK where law teachers have a more formal expectation to provide pastoral support for students, some teachers appreciated its importance and object to it being compromised by administrative demands on their time.

I like the pastoral care of the job. I don't find it stressful. (UK)

They (management) do not set a good example in these respects and often do not seem to care genuinely about the students. (UK)

Overall, many participants report their university fails to consult adequately before introducing changes and this undermines the trust staff might otherwise have in the university's willingness to care about their concerns, which typically are focused on 
student learning and development. Although personal values are not mentioned, it is arguable that these comments reveal a clash between personal and organizational values that has worsened with changes to management style.

\section{Options for Change}

Several law teachers called for improved support to meet the needs of students with mental health issues and other cultural challenges who were at risk of 'falling by the wayside' in a market-driven system. An Australian law teacher suggested their university could adopt the wellness guidelines for students and staff (MindsCount, 2019). Other ideas included improving autonomy support for teachers by, for example, introducing or extending the consultation process so teachers could share their practical knowledge and experience of what students need.

Managers (should be) listening to those who have to implement (changes) so as to appreciate the consequences on those who are directly affected. (UK)

Many advocated stopping the habit of repeated restructures and new systems.

I am over restructuring. I cannot see the point. (Aust)

... new strategies, new forms ... at least so I'm not on 'alert' for something new landing on me. (UK)

Have clear strategies and structures, which allow everyone to feel able to contribute to the organisation. (UK)

Stop 'restructuring'. (Aust)

A few respondents drew on positive psychology perspectives, such as clarity of goals or adopting a strengths focus.

... allow staff to work to their strengths, rather than applying a one size fits all model of performance which constantly has staff focusing on and fearful of their weaknesses. (Aust)

... we all have individual strengths that should be praised rather than expect all domains to be excellent. (UK)

To actually have a culture of success. (UK)

Clarity over the goals - is it research or is it the student experience? (UK)

Better ... acknowledgement of successes. (Aust)

\section{Limitations}

Although the study is not representative because of its voluntary nature, self-reporting methods and small numbers, it provides a valuable snapshot of teachers' perceptions of the causes of stress that may be associated with law student psychological distress. It also adds to the findings of earlier studies and the outcomes provide an important basis for future and larger studies into law teacher wellbeing that might inform systemic and strategic change towards improving the workplace environment for academics and consequently the learning experience and wellbeing of law students.

\section{Conclusions}

Each of us is the university - and to be vibrant and alive, the university must value all within its varied mosaic of active thinkers, researchers and teachers. (Aust)

This research evidenced a values gap within universities in both Australia and the UK and a malalignment of values between academics and institution, as if law teachers and management were operating in separate spheres with few shared goals, priorities or objectives, and in some places little respect. 
Some participants showed signs of distress, calling for changes that might improve what they experienced as a poor system or a surviving or barely adequate one. Several Australian respondents seemed more hopeful, suggesting a 'positive workplace' is possible in legal education, despite the current challenges. According to the HEPI report in the UK, institutions must decide how to allocate work more realistically, to use metrics more responsibly, develop better performance management systems that include long-term goal-setting, and commit to providing staff with sustainable career pathways (Morrish, 2019). The hope of participants in this study is consistent with recent research drawing on positive organisational scholarship (Huang, 2018; Sternlight \& Robbennolt, 2015) and the possibilities of 'positive legal education' (Austin, 2018; Duffy, Field, Pappalardo, Huggins, \& James, 2016; Foley et al., 2016).

While the quantitative results of this project are still under analysis, the qualitative findings in this paper offer valuable understandings of sources of stress experienced by law teachers in both countries. Since both cohorts appear to prioritise law student wellbeing over their own, it helps to confirm the hypothesis that improving the wellbeing of law teachers, by for example reducing sources of stress, reducing their administrative burden and increasing opportunities for direct student-teacher engagement, will likely enhance the wellbeing of law students in ways that might benefit them as they transition into the legal profession.

Krieger and Sheldon's (2015) large empirical investigation into the happiness of lawyers, and their findings, provide us with a further recommendation. That study indicated that the most important factor contributing to lawyer wellbeing is to experience autonomy support at work. Autonomy support is of particular importance where there is a hierarchical relationship as experienced in employment by academic staff (Krieger \& Sheldon, 2015, p. 582). Autonomy support is experienced where the employer provides meaningful choice and where this is not possible explains the reason and, most importantly, acknowledges the perspective of the employee. The qualitative data upon which this article reports is filled with requests for this treatment at work. We would argue that it could easily be provided through changes in law school management style with impressive potential impact for increasing the wellbeing of staff and thus students.

\section{References}

Åkerlind, G. (2012). Variation and commonality in phenomenographic research methods. Higher Education Research \& Development, 31(1) 115-127. https://doi.org/10.1080/07294360.2011.642845

Austin, D. S. (2018). Positive legal education: Flourishing law students and thriving law schools. Maryland Law Review, 77, 649-711.

Bergin, A. J., \& Pakenham, K. (2014). Law student stress: Relationships between academic demands, social isolation, career pressure, study/life imbalance and adjustment outcomes in law students. Psychiatry, Psychology and Law, $21,1-18$. https://doi.org/10.1080/13218719.2014.960026

Bunge, N. (2018). Students evaluating teachers doesn't just hurt teachers. It hurts students. The Chronicle of Higher Education. https://www.chronicle.com/article/Students-Evaluating-Teachers/245169

Davies, W. (2016). The Limits of Neoliberalism: Authority, Sovereignty and the Logic of Competition. Sage.

Deem, R. (1998). 'New managerialism' and higher education: The management of performances and cultures in universities in the United Kingdom. International Studies in Sociology of Education, 8(1), 47-70. https://doi.org/10.1080/0962021980020014

Duffy, J., Field, R., Pappalardo, K., Huggins, A., \& James, W. (2016). The 'I Belong in the LLB' program: Animation and promoting law student well-being. Alternative Law Journal, 41(1), 52-55. https://doi.org/10.1177\%2F1037969X1604100113

Fischer, R., \& Boer, D. (2011). What is more important for national well-being: Money or autonomy? A meta-analysis of well-being, burnout, and anxiety across 63 societies. Journal of Personality and Social Psychology, 101(1), $164-184$. https://doi.org/10.1037/a0023663

Foley, T., Hickie, I., Holmes, V., James, C., Rowe, M., \& Tang, S. (2016). Being Well in the Law: A Guide for Lawyers. The Law Society of New South Wales.

Hil, R. (2015). Selling Students Short: Why You Won't get the University Education you Deserve. Allen \& Unwin.

Huang, P. H. (2018). Positive institutions: Organizations, laws, and policies. In C. R. Snyder, S. J. Lopez, L. M. Edwards, \& S. C. Marques (Eds.), The Oxford Handbook of Positive Psychology (3rd ed.). OUP. 
James, C., Strevens, C., Field, R., \& Wilson, C. (2019). Fit your own oxygen mask first: The contemporary neoliberal university and the well-being of legal academics. In J. M. Marychurch \& A. Sifris (Eds.), Wellness for law: Making wellness core business. LexisNexis.

James, C., Strevens, C., Field, R., \& Wilson, C. (2020). The changing world of legal education: A comparison of law teachers' well-being and perceptions of stress at work in Australia and the UK. In J. Chan, P. Vines, \& M. Legg (Eds.), The impact of technology and innovation on the well-being of the legal profession. Intersentia.

Krieger, L. S. (1998). What we're not telling law students - and lawyers - that they really need to know: Some thoughts-inaction toward revitalizing the profession from its roots. Journal of Law and Health, 13(1), 1-48.

Krieger, L.S., \& Sheldon, K.M. (2015). What makes lawyers happy?: A data-driven prescription to redefine professional success. George Washington Law Review, 83(2), 554-627. https://www.gwlr.org/what-makes-lawyers-happy-a-datadriven-prescription-to-redefine-professional-success/

Lawrence, J. W. (2018). Student evaluations of teaching are not valid. American Association of University Professors. https://www.aaup.org/article/student-evaluations-teaching-are-not-valid

MindsCount. (2019). Wellness Workplace Factors. https://mindscount.org/the-guidelines/the-13-workplace-factors/

Mok, K. H., \& Neubauer, D. (2016). Higher education governance in crisis: A critical reflection on the massification of higher education, graduate employment and social mobility. Journal of Education and Work, 26(1), 1-12. https://doi.org/10.1080/13639080.2015.1049023

Morrish, L. (2019). Pressure Vessels: The Epidemic of Poor Mental Health Among Higher Education Staff. Higher Education Policy Institute.

Ryan, R. M., \& Deci, E. L. (2000). Self-Determination Theory and the facilitation of intrinsic motivation, social development, and well-being. American Psychologist, 55(1), 68-78. https://psycnet.apa.org/doi/10.1037/0003$\underline{066 X .55 .1 .68}$

Ryff, C. (1989). Happiness is everything, or is it? Explorations on the meaning of psychological well-being. Journal of Personality and Social Psychology, 57(6), 1069-1081. https://psycnet.apa.org/doi/10.1037/0022-3514.57.6.1069

Saunders, D. (2007). The impact of neoliberalism on college students. Journal of College and Character, 8(5), https://doi.org/10.2202/1940-1639.1620

Schulze, L. N., \& Ding, A. A. (2012). Alternative justifications for law school academic support programs: SelfDetermination Theory, autonomy support, and humanizing the law school. Ohio Northern University Law Review, 38, 999-1041.

Sims, M. (2019). Neoliberalism and new public management in an Australian university: The invisibility of our take-over. Australian Universities Review, 61(1), 22-30. https://www.nteu.org.au/tas/article/Neoliberalism-and-new-publicmanagement-in-an-Australian-university\%3A-The-invisibility-of-our-take-over-\%28AUR-61-01\%29-21228

Sternlight, J. R., \& Robbennolt, J. K. (2015). Psychology and effective lawyering: Insights for legal educators. Journal of Legal Education, 64(3), 1-21.

Student Minds, (2014). Understanding Provision for Students with Mental Health Problems and Intensive Support Needs. https://www.studentminds.org.uk/summaryofhefcesreport.html.

Thornton, M. (2014a). Legal education in the corporate university. Annual Review of Law \& Social Sciences, 10, 19-35. https://doi.org/10.1146/annurev-lawsocsci-110413-030714

Thornton, M. (2014b). Through a Glass Darkly: The Social Sciences Look at the Neoliberal University. ANU Press.

Wilson, C., \& Strevens, C. (2018). Perceptions of psychological well-being in UK law academics. The Law Teacher, 52(3), 335-349. https://doi.org/10.1080/03069400.2018.1468004

\section{Please cite this article as:}

James, C., Strevens, C., Field, R., \& Wilson, C. (2019). Student wellbeing through teacher wellbeing: A Study with law teachers in the UK and Australia. Student Success, 10(3), 76-83. https://doi.org/10.5204/ssj.v10i3.1338

This article has been peer reviewed and accepted for publication in Student Success. Please see the Editorial Policies under the 'About' section of the Journal website for further information.

Student Success: A journal exploring the experiences of students in tertiary education

(c) (1) This work is licensed under a Creative Commons Attribution 4.0 International Licence. As an open access journal, articles are free to use with proper attribution. ISSN: 2205-0795 